\title{
MEDIEVAL CULTURAL HERITAGE OF POMERANIAN TOWNS. PROBLEM OR POTENTIAL?
}

\begin{abstract}
In the Pomeranian Voivodeship there are 27 small and medium-sized towns with preserved material heritage of medieval architecture and urban planning, entered into the register of historical monuments. The aim of this paper is to analyse the state of preservation of the resources in selected towns in terms of its development potential. The author's attention was directed towards the problems of adaptation, management, development and access to heritage.
\end{abstract}

Keywords: cultural heritage, small and medium-sized cities, medieval times, Pomeranian Voivodeship, management

\section{Streszczenie}

\section{Średniowieczne dziedzictwo miast województwa pomorskiego. Problem czy potencjał?}

W województwie pomorskim znajduje się 27 małych i średnich miast, które posiadają zachowane materialne dziedzictwo średniowiecznej architektury i urbanistyki, wpisane do rejestru zabytków. Celem artykułu jest analiza stanu zachowania posiadanego zasobu wybranych miast pod kątem jego potencjału rozwojowego. Uwaga autora została skierowana na problemy adaptacji, zarządzania, zagospodarowania i udostępniania dziedzictwa.

Słowa kluczowe: dziedzictwo kulturowe, małe i średnie miasta, średniowieczne, województwo pomorskie, zarządzanie

\section{Introduction}

The network of towns and architectural objects created in the period from the $12^{\text {th }}$ to the $15^{\text {th }}$ century on the Baltic Sea constitute one of the most valuable elements of the cultural landscape of Europe and a testament to its turbulent history and 
contemporary identity. As the area of infiltration of Polish influences, Pomeranian dukes and the state of the Teutonic Order, the area of Eastern Pomerania (Gdańsk), now largely encompassing the Pomeranian Voivodeship, is especially interesting. The area of Eastern Pomerania since the earliest times, has played an important strategic role due to the estuary of the Vistula and the possibility of control of the river shipping route and the area of the southern Baltic. The fertile Vistula Delta between Gdańsk and Elbląg was also of great importance as an area of intensive agricultural cultivation. No wonder that the Teutonic Order attempted to seize this area, which finally succeeded in 1309 . The conquest of Pomerania was finally established by the transfer of the capital of the Teutonic Order from Venice to Malbork. The Teutonic Knights founded a number of villages in the conquered territory and strengthened the existing ones and built new towns, creating a network of strengthened resistance points, which they administered to the Second Peace of Torun in 1466. Currently, the most recognizable elements of the medieval heritage of the Pomeranian Voivodeship are the monuments of the port city of Gdańsk and the castle-capital in Malbork (inscribed on the UNESCO heritage list). In addition to the natural qualities of the sea and the Kashubian Lake District, these cities are the main attraction and area of tourist penetration in Eastern Pomerania. Other smaller centres also have a long history and a significant number of monuments, nevertheless, they are definitely less recognizable. Differences in rank, visibility and possessed tourism potential create a significant dissonance of development opportunities. Smaller towns are struggling with the problems of proper use and promotion of their cultural resources. This paper attempts to answer the question how the heritage of the Middle Ages is currently developed, managed and used. Particular attention was paid to the small and medium-sized towns of the Pomeranian Voivodeship. Due to their small spatial scale and limited economic and population base, all problems related to the management of cultural heritage are particularly visible in these centres. An attempt to answer the question raised in the title of the paper required the use of various research methods and a specific course of action. The basic research goal in such a framework can be formulated as an attempt to assess the size, social and political context and use of the tangible medieval cultural heritage in the area of research. In order to achieve this goal it was necessary to: determine the size and condition of medieval tangible cultural heritage in the towns studied; define the methods of development and the functions of the resources under investigation; analyse the place of medieval monuments in strategic and development documents at various levels; determine the guidelines of further use of these monuments.

Research on cultural heritage and cultural landscape in the field of geographic sciences is a multi-faceted process and requires the use of specific methods. The first stage of the research was to determine the group of towns to be analysed. Map number 1 shows towns located within the Pomeranian Voivodeship, taking into account their size and the presence of medieval registered monuments. A total of 27 small (below 20,000 residents) and medium-sized towns (between 21 and 100 thousand residents) were chosen for analysis. The analysis thus excluded three 
cities: Gdańsk, Gdynia, and Słupsk. (Słupsk with almost 92 thousand residents, due to the great difference in cultural heritage potential in relation to small towns, was also excluded from the study).

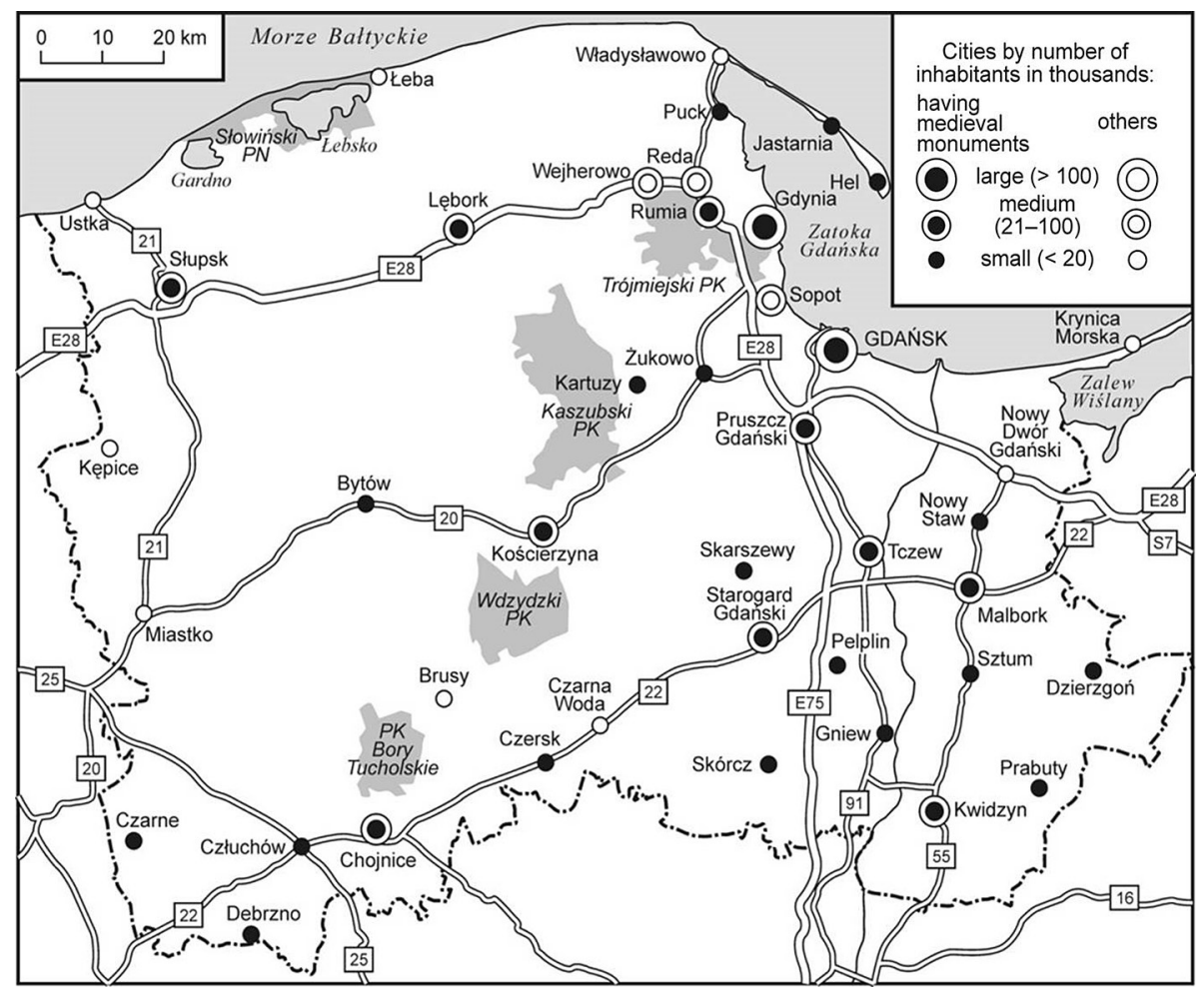

Figure 1. Cities and towns of Pomeranian Voivodeship

Source: author's work.

Data collection was based on field inspection and a query of source materials in the form of development documents and secondary sources, namely printed materials. The author has been conducting field research in northern Poland since 2007, using, among others, social methods (surveys with town residents and tourists, interviews with experts - hotels in monuments owners and workers, municipality members and leaders, local tourism organizations members, etc.), geography of tourism, settlement and historical geography. The knowledge thus gathered, the rich research material, as well as literature, were used as a starting point for the subject matter mentioned in the title of this paper. The basic stage of desk research involved the analysis of selected strategic and development documents of the Pomeranian Voivodeship and Poland. Due to the limited scope of the scientific paper and the complexity of the topic, the focus was on national and 
provincial level documents. In total, 14 studies were examined. The register of monuments of the Pomeranian Voivodeship of December 31, 2017, available on the website of the National Heritage Institute [Narodowy Instytut Dziedzictwa] served as the basis for determining the number, location and period of the creation of individual monuments.

Researching cultural heritage is a complex issue and the framework of the paper does not allow for its comprehensive analysis. The work touched only research topics which require further studies, as selected according to the subjective opinion of the author.

\section{Contemporary role of cultural heritage}

Nowadays, we observe a change in the perception of cultural heritage, as well as new forms of its management and use. The American archaeologist Charles McGimsey [1972] is one of the many scholars (archaeologists, geographers, anthropologists, etnologists, and others), so called forerunners of the change in the approach to the role of monuments in society and economy, who realised that cultural heritage is an inherited wealth that should be managed wisely for the benefit of the general good. Also the British archaeologists have made great strides in this field, as the result of intense work and research related to post-war investments has led to both legal changes and changes in the perception of the archaeologist society in the modern world and responsibility for archaeological heritage [Gutowska, Kobyliński, 2011].

The period of systemic transformation in Poland also brought the recognition that an appropriately developed and managed cultural heritage can bring profits and constitute an incentive for economic development through tourism, job creation and new investments [Derek, 2008; Wyleżałek, 2011; Murzyn-Kupisz, 2012]. Proper management of the historical resources may also contribute to positive social changes among such as increased activation and a sense of local patriotism [Lewandowska, 2003; Musiaka, 2013] among local people, politicians, economists. With the development of the tourist function of historic buildings [Kostrzewa, 1991], threats to the protection, preservation and proper use of heritage began to be recognised [Ashworth, 1999; 2015; Pawłowska, Swaryczewska, 2002]. According to Szmygin [2007], who represents the viewpoint of monument conservators, monuments should be excluded from the process of modern transformations. Currently, the material heritage of past eras is of interest to the dynamically developing trend of cultural tourism [Jędrysiak, Mikos von Rohrscheidt, 2011; MurzynKupisz, 2012; Musiaka, 2013; Hochleitner, 2016]. The development of cultural tourism may pose a threat to monuments, even in a physical manner, such as in frequently visited museums (inflow of mass tourism) or through the loss of historical values in historic buildings adapted for hotels. Sometimes, however, due to the author, this is the only way to provide funds for the reconstruction, survival and use of immovable monuments. Polish precursors in the use of the cultural 
heritage of the Middle Ages to the changing trends were the activities of historical reconstruction groups in Golub Dobrzyń, where knight tournaments have been organised since the 1970s, and in Gniew, where historical reenactment was elevated to a completely new, globally recognised, level [Struczyński, 2013]. This trend continues to this day and has been developed in various forms referring to specific historical events [Hochleitner, 2016] as well as sports and historical events.

At the same time, there were further transformations of the conservationist doctrine, which evolved not only due to the development of technical sciences and conservation methods, but primarily as a result of mass interest in monuments by tourists and the pressure from investors who try to integrate monuments into the market economy in various ways, for example by adapting historic buildings to hotels, restaurants, museums, places of organising tourist events, etc. [Gutowska, 2000; 2003; Kisilowska, 2003; Kłosek-Kozłowska, 2007; Gaczoł, 2009; Kobyliński, 2009; Purchla, 2009]. After 1989, when political and economic transformation in Poland has begun, a visible change in the way of managing cultural resources began, as well as a transition from the model of centralised management and expert criteria for the evaluation of monuments, to public participation, scientific knowledge, negotiations, counselling and interdisciplinarity [Gutowska, Kobyliński, 2011]. Public participation in the process of management and use of monuments includes, among others the recovery of ownership of property plundered during the Second World War and in the era of real socialism by the heirs of former owners, marketization of buying and selling historic properties, local formation of groups, associations caring for monuments (often supported by local authorities), legislative changes in the field of protection monuments (e.g. establishing the position of a social guardian of monuments), bottom-up creation of various types of tourist products (place, product, route, event) based on the heritage, spontaneous creation of fashion for cultural tourism and promotion of cultural heritage through media, social networks, etc., and finally, the participation of local communities in the processes of urban and village revitalization.

The new approach to monument management, although not free from threats, brings many benefits at various levels. On the legal level, this includes the change in the method of financing the protection of monuments and care of monuments includes a partial relief of the state in the issue of financing the protection of monuments and care of monuments by changing the form of ownership of monuments to private, the possibility of obtaining external funds by owners and users of monuments or the possibility of using public-private partnership private state-owned cultural institutions can also run a business [Pruszyński, 2001; Małachowicz, 2007; Kisilowska, 2011]. In 2003, the new Act on the Protection and Care of Monuments was adopted, with further documents regulating the legal issues of the protection and use of cultural heritage in subsequent years [Zeidler, 2014].

At the economic level, heritage treated as a factor of socio-economic development plays a significant role in the promotion of territorial units, attracting investors, tourists, as well as new residents, provides jobs. It is also worth mentioning social benefits, such as increasing the social awareness of possessed heritage 
resources, including citizens in responsibility for monuments and the surrounding space, e.g. by creating a civic budget in cities and the possibility of voting for projects related to spatial development, including historical areas, new forms of education society (publications, multimedia, interactive museum exhibitions, workshops, museum lessons) and, finally, an increase in the sense of local patriotism and local identity based on history and heritage [Rouba, 2005; Wendt, 2010; Murzyn-Kupisz, 2012; Gaweł, 2013; Hausner, Karwińska, Purchla, 2013; Musiaka, 2013; Kozak, 2014, and others].

\section{The size of the resource of medieval heritage}

According to the Report on the state of preservation of immovable monuments in Poland from 2017, objects created from the mid- $13^{\text {th }}$ century to the end of the $15^{\text {th }}$ century amounted to $5.57 \%$ (3,950 objects) of all registered monuments in 2016. The largest number of registered medieval relics are located in the following voivodeships: Lower Silesia (20.2\%), West Pomeranian (15.42\%), Lesser Poland $(11.10 \%)$, Kuyavian-Pomeranian (7.97\%), and Pomeranian (7.44\%) [Raport..., 2017: 78-79]. It should be remembered that this list includes the monuments in Gdańsk and Słupsk, which are not covered by the author's work.

The medieval heritage of the studied area can be divided into two main groups - architectural objects and complexes, and historic urban layouts. Within the first category, castles, churches, monasteries and religious complexes, city walls as well as towers and gates, as well as objects classified as other (such as castle mills, town halls) were distinguished. All registration entries in the examined cities were taken into account, regardless of the condition of these objects, the degree of reconstruction or the rank. There are 5 complexes recognised by the President of the Republic of Poland as Historic Monuments in the voivodeship, two of them are complexes of objects created in the Middle Ages (a Teutonic castle complex in Malbork and a Cistercian abbey and cathedral complex in Pelplin). The Spatial Development Plan of the Pomeranian Voivodship until 2030 includes entries on attempts to recognise the Teutonic castle and the town complex in Gniew as a Historic Monument. The document also lists areas that aspire to be protected in the form of a cultural park in: Bytów, Człuchów, Kartuzy, Kwidzyń, Łeba, and Sztum [Program..., 2017: 173-174].

There are 19 historic town layouts from the medieval period entered in the register, including two rural layouts within the limits of modern towns, which were not towns in the period of location (Skórcz and Jastarnia). Of the 14 castles in the voivodeship entered in the register of monuments, 9 are located in the examined towns (including 4 listed as complexes of objects in Malbork, Kwidzyń, Sztum and Gniew), 21 sacral buildings and complexes, 9 defensive walls, city gates and towers listed as separate objects -5 , objects classified as others -21 (including 2 complexes). 


\section{Condition and development of medieval objects}

The paper takes into account the general state of preservation of monuments, which in the case of medieval objects of the Pomeranian Voivodeship, in comparison with other areas, may be described as very good, since these objects are extremely durable and resistant to various types of threats. However, they are also subject to physical and biological destruction processes, as well as to demolition or improper renovation. Also dangerous and recently clearly growing trend is unsupported with proper documentation of reconstruction, revalorization of objects entered as a ruin in the register of monuments. This mainly applies to castles and some churches. Interestingly, even in this group single cases of demolition were found, which should arouse very serious doubts from the conservatory point of view. According to the Raport o stanie zachowania zabytków nieruchomych w Polsce [2017: 138, 151], among architectural objects built up to the end of the $15^{\text {th }}$ century, entered into the Pomeranian register of monuments, 4 , that is $1.42 \%$ of all Pomeranian registry monuments, are particularly endangered objects that still have not lost their historical values. Such example can be a small, few times rebuild castle in the village of Grabiny-Zameczek. One interesting example of improper treatment may be the first period of reconstruction of the Gniew castle in the 1970s, when concrete ceilings were added to the building. Some of the objects survived only in a residual form and have been preserved as ruins or fragments of former buildings. Very rarely, the objects under investigation have kept only their original stylistic features, while their current form is the result of multiple reconstructions. In extreme cases, only the cellars, fragments of the basement and walls have survived from the original Gothic structure.

The preservation state of monuments is often due to their function. The largest number of historic buildings and complexes of the Pomeranian Voivodship performs sacral functions. The castle chapels in Malbork and Gniew, the Kwidzyń cathedral, which is a part of the castle complex, and the former salt granary in Lębork, which is now the seat of the Pentecostal congregation, also fulfil sacral functions. Apart from castles, museum functions are also filled by some towers and city gates as well as present and former sacral objects. The hotel and catering function is present, among others, in castles in Gniew, Bytów, and Malbork. The standard of services provided varies, but in the towns under investigation, high standard hotel facilities are located within the castle complexes. Some of the facilities perform the functions of cultural centres, libraries, etc. (Bytów, Skarszewy). Another element of the medieval heritage of the cities in question are urban fortifications, which most often serve as tourist information points. There are walking routes and recreational areas in the form of squares, green areas and playgrounds around the former fortifications in some towns. Other register entries mainly include cemeteries, Gothic fragments of tenement houses or town halls, and commercial facilities. Apart from architectural monuments, the spatial layouts of the towns under investigation are also in varied states of preservations. In 
Table 1

Contemporary functions of medieval monuments in small and medium-sized towns of the Pomeranian Voivodeship, entered into the register of monuments*

\begin{tabular}{|c|c|c|c|c|}
\hline $\begin{array}{l}\text { Function/ } \\
\text { object }\end{array}$ & Castle & Sacred object & $\begin{array}{l}\text { Locks, towers, } \\
\text { city gates }\end{array}$ & Other objects \\
\hline Sacral & $\begin{array}{l}\text { Gniew, Kwidzyń, } \\
\text { Malbork }\end{array}$ & $\begin{array}{l}\text { Chojnice, Gniew, Kartuzy, } \\
\text { Kwidzyń, Lębork, } \\
\text { Malbork, Nowy Staw, } \\
\text { Pelplin, Prabuty, Pruszcz } \\
\text { Gdański, Puck, Starogard } \\
\text { Gdański, Skarszewy, } \\
\text { Skórcz, Tczew, Żukowo }\end{array}$ & & Lębork \\
\hline $\begin{array}{l}\text { Museum, } \\
\text { exhibition }\end{array}$ & $\begin{array}{l}\text { Bytów, Człuchów } \\
\text { Gniew, Kwidzyń, } \\
\text { Malbork, } \\
\text { Skarszewy, Sztum }\end{array}$ & $\begin{array}{l}\text { Bytów, Hel, Kartuzy, } \\
\text { Pelplin, Prabuty }\end{array}$ & $\begin{array}{l}\text { Chojnice, } \\
\text { Debrzno, } \\
\text { Lębork, } \\
\text { Prabuty, } \\
\text { Starogard } \\
\text { Gdański }\end{array}$ & \\
\hline $\begin{array}{l}\text { Hotel } \\
\text { services }\end{array}$ & Bytów, Gniew & & & \\
\hline Gastronomic & $\begin{array}{l}\text { Bytów, Gniew, } \\
\text { Malbork, } \\
\text { Skarszewy }\end{array}$ & & Malbork & \\
\hline $\begin{array}{l}\text { Tourist } \\
\text { information }\end{array}$ & $\begin{array}{l}\text { Bytów, Chojnice, } \\
\text { Człuchów, Gniew, } \\
\text { Malbork }\end{array}$ & & $\begin{array}{l}\text { Debrzno, } \\
\text { Prabuty }\end{array}$ & \\
\hline Public utility & Bytów, Skarszewy & & Lębork & $\begin{array}{l}\text { Gniew, } \\
\text { Malbork }\end{array}$ \\
\hline Residential & Malbork & & $\begin{array}{l}\text { Starogard } \\
\text { Gdański }\end{array}$ & $\begin{array}{l}\text { Chojnice, } \\
\text { Gniew, } \\
\text { Kartuzy }\end{array}$ \\
\hline
\end{tabular}

* The list does not take into account ruined and undeveloped objects, historic cemeteries, landscaping and urban layouts. Lębork city walls and fortifications were taken into account, even though they are not protected by an entry in the register of monuments.

Source: author's work.

the Pomeranian Voivodeship there are both very well-preserved layouts, such as Nowy Staw in Żuławy, and almost completely destroyed ones, with original relics preserved, as in the case of Malbork, where a housing estate was built in the place of the old town after the Second World War. 


\section{Tourist product of the medieval heritage}

The described resources of material heritage are the object of interest for the participants of the tourist traffic. From the supply side, responsible entities, in addition to the appropriate development, make attempts to develop tourist products within the cultural tourism trend. From the point of view of the development of the tourist function, one of the important tourism products are routes and events. Tourist routes that allow one to visit objects of medieval heritage include the Pomeranian St. James Trail, the Pomeranian Loop of the Cistercian Route, the Copernicus Route, the Powiśle Castles Trail, the Powiśle Church Trail and the Vistual Cycling Route. The most recognisable route, directly associated with the Middle Ages, is undoubtedly the car route of the Gothic Castles, created and maintained by the association of municipalities "Polish Gothic Castles" based in Olsztyn. The Association has a total of 16 member municipalities, with the following located in the Pomeranian Voivodeship: Bytów, Człuchów, Dzierzgoń, Lębork, Malbork, Sztum, Gniew and Kwidzyń [Stowarzyszenie gmin...]. The organisation's activities largely relieve the municipalities that are its members in the promotion of heritage among tourists. Pomeranian St. James Trail, the Pomeranian Loop of the Cistercian Route and the Copernicus Route in the area of the Pomeranian Voivodship form part of the routes of national and international importance. The same is true of the Vistula Cycling Route. The Powiśle Castles Trail and the Powiśle Church Trail are regional routes [Pomorskie.travel, 2018; PTTK...]. Figure 2 presents map of the cultural routes in Pomorskie Voivodeship based or included medieval cultural heritage.

These trails are usually created and financed by Pomeranian authorities of various levels. Routes of local importance are created mostly by gmina and poviat municipalities, those with regional scope - by the province governments, etc. Especially worthy of mention are supra-regional initiatives which shows that cooperation between various local governments in the area of promotion and management of heritage is possible. A small number of cultural local routes in the Pomeranian province, based on the medieval heritage, and their short period of functioning, shows that on the one hand, there is still a lot of work to improve in the field of promotion of cultural resources at this level, and on the other hand, there is great need to improve tourist infrastructure in the area. Information about the exact course of a given route, attractions and amenities located on the route, etc., are available on dedicated brochures, leaflets and promotional publications, distributed through tourist information centres and during tourist events in the region and travel trades, as well as on the Internet. Unfortunately, it is not possible to find information about all the routes based on the medieval heritage in the Pomeranian Voivodeship on one internet portal. In order to make a map in Figure 2 and collect information about various routes, the author had to search for information on several different websites. According to the author, this testifies again to the lack of coordinated activities in the field of promotion of heritage tourism. 


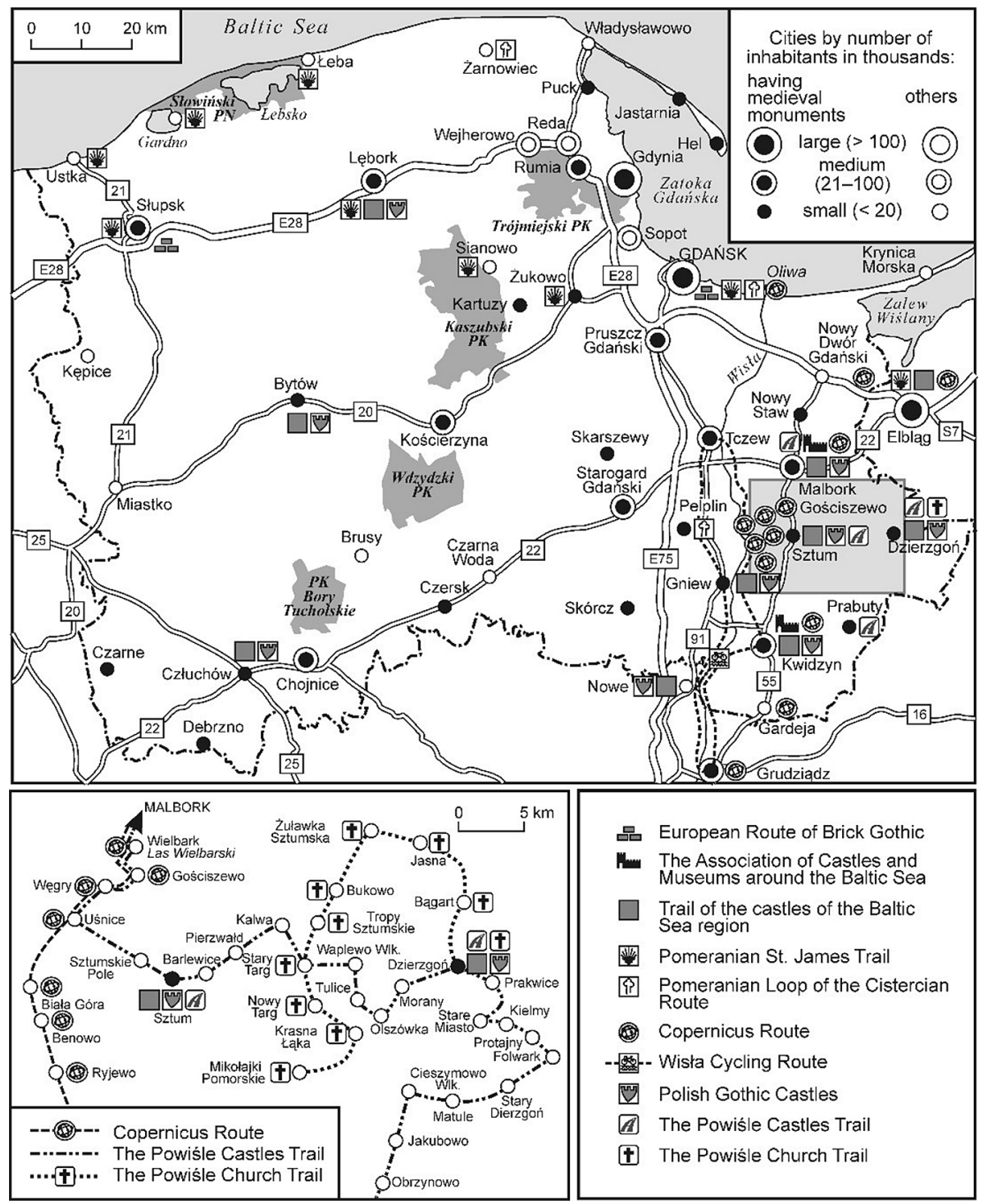

Figure 2. Map of the Pomeranian cultural routes based or included medieval heritage

Source: own elaboration based on promotional materials and Internet sources. ${ }^{1}$

${ }^{1} \mathrm{http} / / / w w w . e u r o b . o r g / w p-c o n t e n t / b l o g s . d i r / s i t e s / 203 /$ europejski-szlak-gotyku-ceglanego-eurob-info-2018.pdf; https://chelmno.pl/wp-content/uploads/2016/09/kartka-eurob.jpg; https://pl.wiki-pedia. org/wiki/Europejski_Szlak_Gotyku_Ceglanego; http://www.visitcastles.eu/castles-around-baltic-sea; http://www.tacis.zamkigotyckie.org.pl; http://www.xacobeo.fr/ZE4.05.Pologne_voi.htm; https://www. trojmiasto.pl/wiadomosci/Trojmiejski-odcinek-Pomorskiej-Drogi-sw-Jakuba-n119132.html?id_zdjecia=336677; https://www.trojmiasto.pl/wiadomosci/Trojmiejski-odcinek-Pomorskiej-Drogi-swJakuba-n119132.html?id_zdjecia=336677\#fb_id:p0:336677,pozycja:5; http://www.re-create.pl/biura/ 
The second group of tourist products, which essentially form the region's brand, are event-type products. In the case of events based on the heritage of the Middle Ages, we can distinguish two categories: military events, and medieval fairs and accompanying events. The most famous knight tournaments of the voivodeship are: King John the 3rd's International Equestrian Knights' Tournament in Gniew, the Siege of Malbork, Open Traditional Archery Tournament in Lębork, and the Grand Tournament of Pomeranian Griffin in Bytów. The Pomeranian Voivodeship is also home to one of the most active reconstruction and re-enactment centres in Poland: the Historical Amusement Park in Gniew Castle. The activity of the castle reenactors was appreciated by the Polish Tourist Organisation. The Siege of Malbork in July is an interesting cyclical event attracting considerable audience [Hochleitner, 2016]. In 2015, an international rank event - the Medieval Combat World Championship - took place in Malbork, which became an excellent opportunity to promote the region as well as the whole country [Musiaka, 2016]. Described events are organized mostly by cultural institutions, users and owners of the castles and the historical reconstruction association. Local governments of various levels support such initiatives through co-financing and promotion. Unfortunately, co-financing from local government resources is not always sufficient and events of considerable importance sometimes face organizational problems [Hochleitner, 2016]. Nevertheless these events have found a proper place in the calendar of cultural events in the cities and whole region, and enjoy the interest of both tourists and residents. The fair category includes events such as the Cistercian Fair in Pelplin, the Lębork St. James Days and the Lavender Fair of St. James in Człuchów. The rank of these events should be defined as local. According to the author, they constitute an attempt to attract tourist traffic to the towns which are not in the top tourist league of the Pomeranian Voivodeship. They are also oriented on local residents, which is especially important in smaller towns, with lower access to the cultural services sector. These are very important initiatives that are organized or supported by local governments. It should be noted that regardless of the importance of the event or the venue of the event, they constitute an important alternative to tourism based on natural resources (e.g. 3 "S" type) and an important complement to the cultural tourism offer. According to the author, in the following years, another event-type tourist products will appear on the Pomeranian touristic map.

\footnotetext{
PomorskiSzlakSwJakuba/page_download/7/RECReate\%20-\%20prezetacja.pdf; http://www.muzeum. diecezja.org; https://papers.wsb.poznan.pl/studia-periegetica-issue/2; http://www.sztum.pl/sciezki-pieszo-rowerowe.html; https:/www.polskieszlaki.pl/szlak-kopernikowski.htm; https://pomorskie.travel//en/Discover-On_a_trail-Wis_a_Cycling_Route; http://www.szlaki.mazury.pl/; https://www. traseo.pl/trasa/szlak-zamkow-gotyckich; http://zamkigotyckie.org.pl/wp-content/uploads/2018/05/zamki oferty_2016_ang.pdf; http://powislanska.pl/project/szlak-rowerowy-2; http://kologotyku.pl/r,26298, pl,szlak_kosciolow_powisla_niebieski.html; https://pomorskie.travel/pl/-/szlak-kosciolow-powisla [accessed: 25 June 2018].
} 


\section{Tourist traffic}

The global size of tourist traffic as part of cultural tourism in the towns studied is difficult to determine. According to the author, the most reliable way to estimate it is to analyse the tourist arrivals recorded by the region's castles. The tourist rank of the old strongholds measured according to the size of the recorded tourist traffic is presented in table 2. By far the most visited object is the Malbork Castle, where the annual number of visits exceeds 500,000 [Musiaka, 2016]. The other strongholds are not able to even approach this size and record from several dozen to several thousand visitors annually, calculated according to the admission tickets sold. However, it should be noted that historical events organised at the Gniew Castle, according to the organisers (owners of the Gniew Castle), can attract up to several tens of thousands of visitors. Objects other than castles usually do not have statistics of visits. Ranking the elements of the medieval material heritage according to their tourist attractiveness may serve as a certain point of reference in this regard. Castles are most significant in the region, followed by sacral monuments, walls and municipal fortifications, as well as historical urban layouts. The significance of objects classified as others varies. Of course, each town should be treated separately, and the presented summary only shows some general trend in tourist behaviour.

Table 2

Tourist rank of the Pomeranian castles according to the size of recorded tourist traffic

\begin{tabular}{|l|l|l|l|l|}
\hline \multirow{2}{*}{} & \multicolumn{4}{|c|}{ Rank } \\
\cline { 2 - 5 } & \multicolumn{1}{|c|}{ International } & National & Regional & Local and supralocal \\
\hline Castle & Malbork & Gniew, Bytów & Człuchów, Kwidzyń & Sztum, Skarszewy \\
\hline
\end{tabular}

Source: modified from: Musiaka, 2013: 63.

The second, extremely important element of the phenomenon of tourist traffic is its seasonality. According to studies by Kostrzewa [1991] and the author [Musiaka, 2013], tourist stays in the analysed cities can be described primarily as short-term and seasonal. The tourist season lasts from June to August in the case of individual tourism, and is extended to May and September in the case of organised tourism (school trips, conference tourism). The average length of tourist stays usually does not exceed a few hours, which translates into low income from tourism in the reception area. The local government and local entrepreneurs are forced to look for ways to extend the tourist season and keep visitors in their towns for longer. According to the Regional Strategic Program "Pomeranian Journey", "seasonality makes the potential of a rich cultural and tourist offer (...) insufficiently utilised, and the image - seen through the prism of the sea and the beach - has a negative impact on the region's economy [Strategia..., 2004: 7]. 


\section{Functional and ownership changes}

Functional and ownership changes affect castles the most. In the last 20 years, a significant number of former strongholds in Poland have been sold or leased to private investors and adapted to perform new functions (in the Pomeranian Voivodeship: Przezmark and Stara Kiszewa, and in other regions of the country, for example Korzkiew, Bobolice, Ryn, Morag, Giżycko, and the lower town in Lidzbark Warmiński). In the Pomeranian Voivodeship, the largest transaction of this type was the sale of the castle in Gniew in 2010. The facility, managed by the local self-government through the "Gniew Castle Foundation", despite its growing reputation in the domestic tourist market, was unable to complete the necessary repairs and renovation works. The cost of replacing the roof itself exceeded the budgetary constraints of the town and the municipality. Castle hill buildings were valued at PLN 41 million. After 2.5 years of negotiations, the castle hill was sold for nearly PLN 15 million, and the new owner has allocated over 100 million for necessary technical and adaptation works [ANND, ASL, 2010]. Big changes also took place in the Sztum castle. The City Hall and Municipal Office of Sztum tried to sell the castle complex five times. Finally, in January 2018, the buildings of the Sztum castle were transferred to the Treasury to create a branch of the Malbork castle [Urząd Miasta i Gminy w Sztumie, 2018].

Another example is the castle in Malbork, which, despite being the seat of the Castle Museum, conducts commercial activities as an organiser of conferences and trainings. The facilities of the Karwan Conference Centre located in the lower castle are mainly used for this purpose. Some of the castle facilities were leased to a private investor to serve as hotel facilities. The contract has been terminated and the facilities are now waiting for a new tenant from the hotel industry. The remains of the Człuchów castle were also requalified in 2013 as the seat of the Regional Museum.

Functional changes also apply to other elements of medieval heritage, such as urban fortifications. Obviously, large objects such as towers, locks and city gates are best for the purpose, and they are adapted for tourist and municipal services. However, another trend is also visible, namely the adaptation of medieval fortifications and their direct surrounding to recreation functions - hiking and leisure. Urban tourist routes are created, and investments are made to improve the surface of car and pedestrian routes along the old fortifications, with new playgrounds, green areas, information boards and small architecture. The old fortifications in Tczew, Malbork, Starogard Gdański, Gniew, and Prabuty can serve as an example. The town fortifications in Lębork, protected under the Local Spatial Development Plan, were also subject to re-valorisation and revitalisation. 


\section{Medieval heritage in strategic documents}

When trying to define the role of the medieval heritage in strategic documents, the author reviewed studies in the field of tourism, monument protection, spatial development and so-called general development. In the field of tourism, these were: Tourism Development Strategy for the Pomeranian Voivodeship for the years 2004-2013, Regional Strategic Program in the area of cultural and tourist attractiveness "Pomeranian Journey", Pomeranian Tourism Product Development Program for 2008-2013, Product development concept of 4 cultural tourism routes and Tourism development program until 2020. Other documents include: Regional Operational Program of the Pomeranian Voivodeship for the years 2014-2020, Spatial Development Program of the Pomeranian Voivodeship 2030, Spatial Development Plan of the Pomeranian Voivodeship, Development Strategy of the Pomeranian Voivodeship until 2020, Care program for monuments of the Pomeranian Voivodeship for 2016-2019, Report on the state of preservation of immovable monuments in Poland. Monuments entered in the register of monuments (register books A and C). Also, local level documents were used as auxiliary sources: Study of launching a year-round tourist product of the Municipal Functional Area of Malbork, Municipal Program for the Care of Monuments of the City of Lębork for 2015-2018 and Local Program for Revitalisation of Nowy Staw until 2020. Diagnosis of Degraded Areas and Revitalisation.

In the table 3 the role of Pomeranian medieval cultural heritage in tourist development strategic documents has been presented. Apart from their thematic scope the documents analysed can be divided according to the time of creation.

In older studies, the emphasis is put on tourist attractiveness of the castles in the region, while other elements of medieval heritage are omitted. Moreover, none of the development strategies mention the need for cooperation with neighbouring voivodeship in terms of promotion, and joint creation of the image and brand of supra-regional products. They instead focus on competitive activities and a struggle for the voivodeship to stand out from other regions. Newer studies and, interestingly, documents from outside the tourism area, already take into account the need for appropriate cooperation, also at the international level (which in practice is very hard to achieve). They focus on infrastructure development, joint promotion and creation of new tourist products at every level of management. In the Spatial Development Program of the Pomeranian Voivodeship 2030, attention is paid to the need to protect and fully re-valorise historic urban layouts. This problem is absent in the strategies in the field of tourism. The medieval heritage of the Pomeranian Voivodeship is undoubtedly considered one of the most valuable elements of the cultural landscape of Pomerania and the whole country. This legally protected historic resource is extremely valuable for historical, artistic and aesthetic, scientific and educational reasons, as well as for some religious ones. It also has significant commercial value. Nevertheless, the conclusions drawn from the reading of strategic studies for the voivodeship and the country allow to define the complex of medieval architecture and Pomeranian town planning as a resource with still unused development potential. 


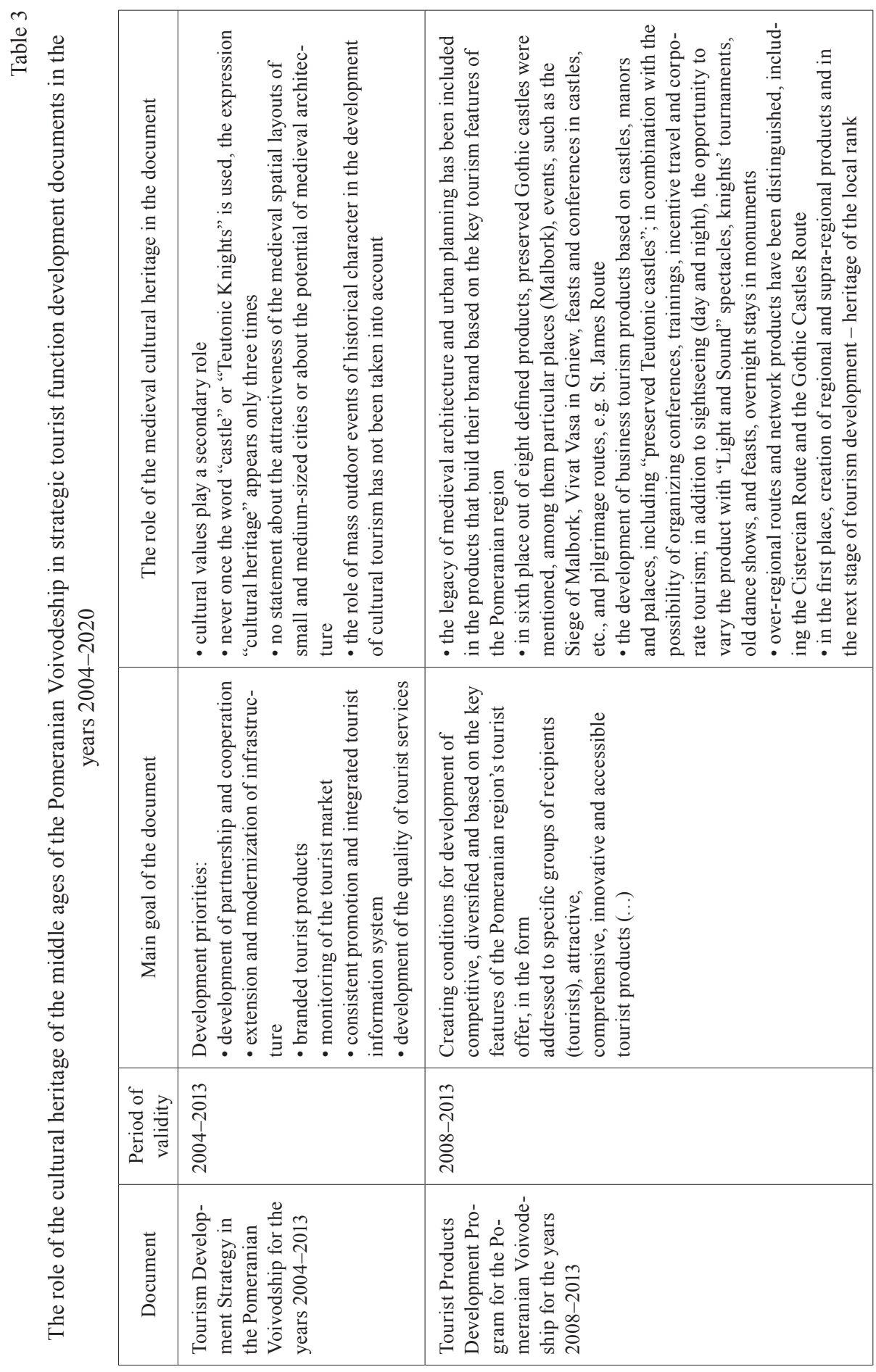


$\dot{0}$
$\dot{0}$
0
0
0

\begin{tabular}{|c|c|c|}
\hline 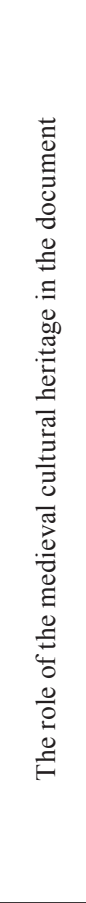 & 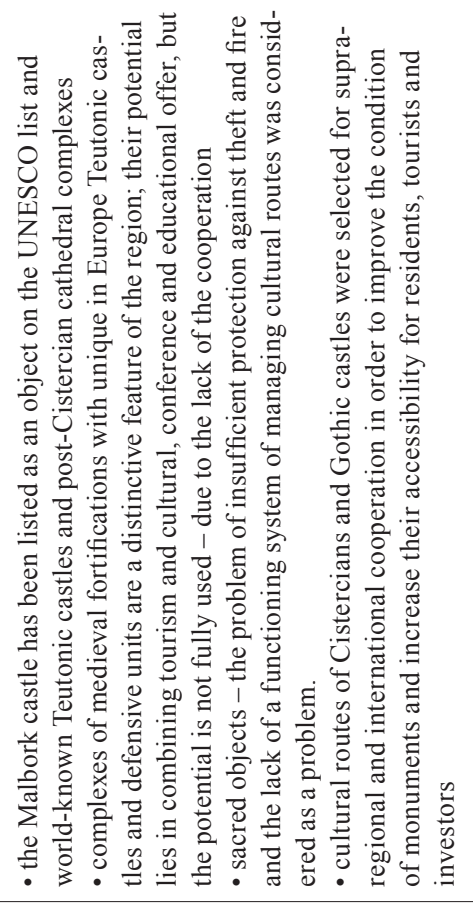 & 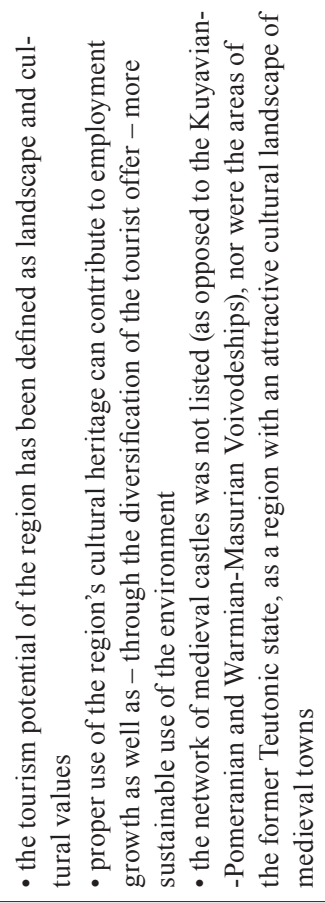 \\
\hline 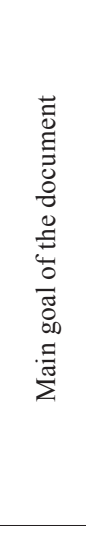 & 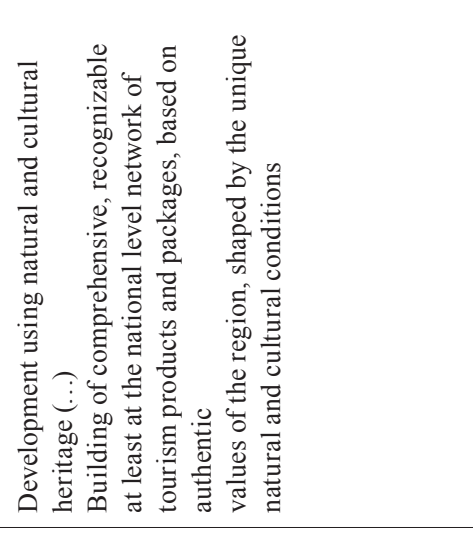 & 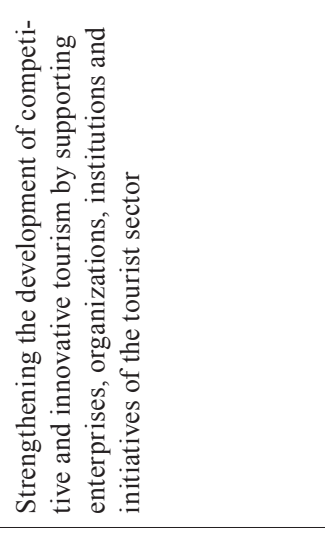 \\
\hline 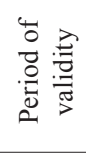 & 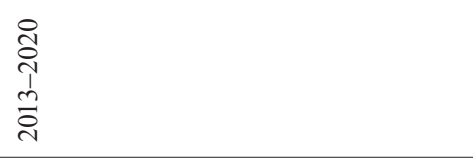 & 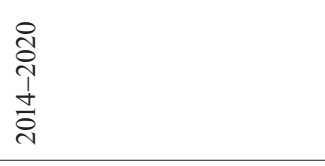 \\
\hline 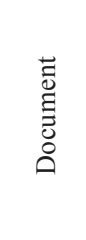 & 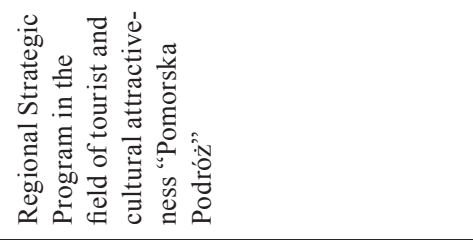 & 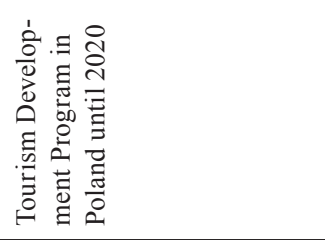 \\
\hline
\end{tabular}




\section{Analysis and discussion}

The main problems of using the examined objects and areas defined in the course of analysis can be divided into two main groups - technical and financial problems, and management problems. The first group consists mainly of problems with maintaining the technical condition of the buildings, resulting from the lack of funds of the owners or users of monuments. The second group includes problems consisting in the lack of cooperation between entities using individual objects operating on the market, lack of ideas on how to properly use and attract the customers, and the attitude of commercial entities in monuments prioritising competition rather than cooperation.

The first problem group is clearly represented by the example of the Gniew castle. Despite its good management and commercial success, technical and conservation problems were too big for the budgetary means of a small town, which meant that the historic complex had to be sold to a private entity. In turn, the example of the Sztum castle shows that the sale of a large object or a complex of objects is not always a simple task and can last for years. This leads to a reflection that perhaps the market of luxury hotels in northern Poland is reaching saturation. Some opportunities for obtaining funds by local administration, also for revitalization and revalorisation of cultural heritage, are offered by publicprivate partnership (PPP). This form of financing tasks and investments has been known in Poland since the 1990s, but it is still used on a low level [Raport..., 2013: 15]. In the Pomeranian province, good example of the investment in this formula can be process of the revitalization of the northern part of the Island of Granaries (Wyspa Spichrzów) in Gdańsk [Partnerstwo Publiczno-Prywatne]. Perhaps the local governments of other towns and cities will also decide to look for funds in this formula.

The second category of problems is visible only from the perspective of a group of objects, not individual monuments. It is marked by the lack of cooperation between the entities managing the castles, the still unused potential of creating cultural routes, linking elements of medieval heritage other than castles, underutilisation of city walls and fortifications, and historic urban layouts of the voivodeship. It also seems that religious tourism also has a large development potential in Pomerania. Teutonic castles are, after all, former monasteries-fortresses. Further possibilities of commercially using this resource can be found in the market of weekend, educational and business tourism, offers aimed at the inhabitants of the region, as well as the historical reconstruction and reenactment movement. The medieval combat events are often held in isolation from the medieval monuments. One big problem in the development of the province's cultural tourism is the very high seasonality of tourist arrivals, the low rank of some monuments and the lack of attractions that could stop tourists and visitors in the reception area for more than a few hours. Peripheral location in relation to the largest cities and a specific location in the road network also have a significant impact on the development of tourism based on existing cultural resources. The financial problems of objects 
of lesser importance, financial and personnel failure of the conservation service are a common phenomenon. Often, however, the biggest problem is not the lack of funds but the lack of ideas on how to better use the heritage of the Middle Ages for local communities and for visitors.

The decentralisation of the planning system in Poland has transferred the burden of responsibility for the care, protection and adaptation of some monuments to new functions to local governments. This forced the sale of some monuments into private hands, as well as functional changes. With the growing demand for cultural heritage, the supply of commercial services, such as hotels, gastronomy, events, conference tourism, incentive and others have developed [Rouba, 2005; Kaczmarek, Stasiak, Włodarczyk, 2008; Szmygin, 2009]. In Pomerania and in the whole country, tourist packages aimed at commercialisation of cultural heritage began to be created [Narożniak, 2002; Struczyński, 2013; Studzieniecki, 2013]. Commercialization of heritage under the current system of financing protection of cultural heritage often becomes the only way to preserve it and restore its usability. However, deciding to sell the elements of heritage, it should be remembered that, on the one hand, the full possible protection of the original historic resource and respect for the conservative doctrine should be assured, and on the other hand, constitutional, common access to cultural goods to the public should be guaranteed. Currently, the administrators of historic buildings and local government authorities are looking for new attractions, solutions, opportunities for cooperation, promotion and development of the tourist function based on the values of cultural heritage. A great example of the described processes is the material heritage of the Middle Ages in the former Teutonic state in Prussia. The new trends primarily concern the most attractive part of the medieval heritage, namely castles [Szwichtenberg, 2002; Rouba, 2005; 2010a; 2010b; Wendt, 2010; Kozak, 2014; Musiaka, 2016]. In order to effectively manage such heritage in a rapidly changing world, it is necessary to outline a clear vision, mission and goal of action. To this end, general and industry development strategies are being developed [Stasiak, Rochmińska, 2011; Studzieniecki, Wołoszyk, 2013; Musioł-Urbańczyk, Sorychta-Wojsczyk, 2017]. To a certain extent, expert studies are forced to fill the gap at the level of scientific research on cultural heritage, primarily in the role and importance of cultural heritage for local development (social and economic) and use for tourist function. As M. Murzyn-Kupisz [2012: 11] writes, "despite the topicality of the subject, the issue of cultural heritage as a modern development resource has so far not been adequately reflected in scientific works in the field of regional economy published in Poland".

\section{Summary}

To sum up, the answer to the question formulated in the title is not clear, considering the complexity of the processes of the socio-economic and legal environment, the diversity of forms, ranks, states of preservation and the functions 
fulfilled by elements of medieval heritage. Monuments of architecture and urban planning from the $13^{\text {th }}-15^{\text {th }}$ centuries constitute the foundations of the cultural heritage of Pomerania, but it is a potential that is not free from various problems. Some hope for improvement can be found in the improving general technical condition of objects, functional and qualitative changes in the monuments, as well as in better promotional activities and the creation of new tourist products. According to the author, the whole area under analysis requires constant investments in infrastructure, promotion, creation of new tourist products and supporting attractions, combination of cultural offer with active tourism based on natural values, creating ideas for managing heritage objects other than castles and strong cooperation between cities and sectors of the tourism industry, local governments and non-governmental organisations (networking). To achieve this, local authorities should be made aware and convinced of the rightness of such actions, and soon after all other interested entities from the tourism and cultural industries should be aware of the need of change and cooperation. Perhaps a good idea would be to organize regular trainings with real specialists and practitioners from the heritage tourism industry, combined with study visits in areas that have achieved success in this area. It should also be ensured that there is a constant opportunity to exchange ideas, experiences and monitor the activities undertaken for experts, local government, entrepreneurs, cultural institutions, local action groups and residents. There is a great role for the local governments to play the role of ignition of change and being a patron of such works. This would give ground for the creation of a regional tourist cluster. The next stage should be the detailed definition of the possessed development potential of the voivodeship and its parts, and the implementation of a series of sociological research, both with tourists and residents of Pomerania, regarding their needs and expectations in the field of tourism development and the use of heritage. For this purpose, Pomeranian universities, especially those units educating in the field of tourism, marketing and management, may be invited to cooperate. In the next step, it would be necessary to analyze the collected material, make financial calculations and development of the strategy, required legislative changes and development directions based on mutual cooperation of local governments, local action groups, cultural objects, tourism industry, and finally voivodeship residents. The next, extremely important step, would be the issue of financing infrastructure investments, educational (for residents) and training (for interested entities), promotion, research and monitoring. The outlined activities should be guided by two basic ideas. The first - mutual, close cooperation, support, creating network products, not direct competition and acting as individuals. The second is the attitude concentrated on long-term action, resistant to the tenure of the government and self-government authorities as well as economic fluctuations. Next stage should be looking for the broader, supra-regional co-operators. Without the introduction and intensification of these activities, the cultural heritage of the region's small and medium-sized towns in terms of commercial use will still be only a back-up for coastal leisure and active tourism. However, in the pursuit of commercial 
success, it should be remembered that the material heritage of the past generations does not only mean valuable historic substance, but also the duty to preserve, conserve and maintain it in the best possible condition.

\section{References}

ANND, ASL (2010) Zamek w Gniewie ma nowego właściciela, “TVP Info”, http://www.tvp. info/2152866/zamek-w-gniewie-ma-nowego-wlasciciela [accessed: 25 June 2018].

Ashworth G.J. (1999), Dziedzictwo a turystyka: zarzadzanie kryzysem zasobów [w:] J. Purchla (red.), Dziedzictwo a turystyka, Międzynarodowe Centrum Kultury, Kraków.

Ashworth G.J. (2015), Planowanie dziedzictwa, Międzynarodowe Centrum Kultury, Kraków.

Derek M. (2008), Turystyka kulturowa a rozwój gospodarczy, czyli: czy Frombork żyje z turystyki? [w:] A. Kowalczyk (red.), Turystyka kulturowa. Spojrzenie geograficzne, Wydawnictwa Uniwersytetu Warszawskiego, Warszawa.

Gaczoł A. (2009), Ochrona zabytkowego miasta. Rzeczywistość czy fikcja, WAM, Kraków.

Gaweł Ł. (2013), Zarzadzanie dziedzictwem kulturowym - w stronę nowej metodologii, "Problemy Zarządzania”, 11 (4).

Gutowska K. (2003), Niechciane dobra kultury: chronić czy niszczyć? [w:] K. Gutowska (red.), Dziedzictwo kulturowe - konteksty odpowiedzialności, Warszawa.

Gutowska K. (red.) (2000), Problemy zarzadzania dziedzictwem kulturowym, Res Publica Multiethnica, Warszawa.

Gutowska K., Kobyliński Z. (2011), Zarzqdzanie dziedzictwem kulturowym - nowa dziedzina nauczania akademickiego i badań naukowych, "Mazowsze. Studia Regionalne", 6.

Hausner J., Karwińska A., Purchla J. (red.) (2013), Kultura a rozwój, Narodowe Centrum Kultury, Warszawa.

Hochleitner J. (2016), Inscenizacje historyczne w Muzeum Zamkowym w Malborku [w:] J. Hochleitner (red.), Wyzwania turystyki kulturowej w Malborku, Muzeum Zamkowe w Malborku, Malbork.

Jędrysiak T., Mikos von Rohrscheidt A. (2011), Militarna turystyka kulturowa, Polskie Wydawnictwo Ekonomiczne, Warszawa.

Kaczmarek J., Stasiak A., Włodarczyk B. (2008), Przestrzeń gościnna - kilka uwag o konkurencyjności regionów [w:] G. Gołembski (red.), Turystyka jako czynnik wzrostu konkurencyjności regionów w dobie globalizacji, Wydawnictwo Akademii Ekonomicznej w Poznaniu, Poznań.

Kisilowska H. (2003), Wykorzystanie nieruchomości zabytkowych na cele użytkowe [w:] K. Gutowska (red.), Dziedzictwo kulturowe - konteksty odpowiedzialności, Warszawa.

Kisilowska H. (2011), Prawne aspekty ochrony nieruchomości zabytkowych, "Mazowsze. Studia Regionalne", 7.

Kłosek-Kozłowska D. (2007), Ochrona wartości kulturowych miast a urbanistyka, "Zeszyt Architektura", 4.

Kobyliński Z. (2009), Własność dziedzictwa kulturowego. Idee - problemy - kontrowersje, Instytut Archeologii i Etnologii PAN, Warszawa. 
Kostrzewa J. (1991), Funkcja turystyczna zamku w Malborku w świetle ruchu turystycznego, "Turyzm", 1 (1).

Kozak M. (2014), Gotyckie zamki ceglane: szansa czy problem?, "Turystyka Kulturowa”, 5. Lewandowska I. (2003), Historyczna świadomość regionalna. Z badań nad młodzieża licealnq Warmii i Mazur, Towarzystwo Naukowe, Ośrodek Badań Naukowych im. Wojciecha Kętrzyńskiego, Olsztyn.

Małachowicz E. (2007), Konserwacja i rewaloryzacja architektury w środowisku kulturowym, Oficyna Wydawnicza Politechniki Wrocławskiej, Wrocław.

McGimsey C.R. (1972), Public Archeology, Seminar Press, New York-London.

Murzyn-Kupisz M. (2012), Dziedzictwo kulturowe a rozwój lokalny, Publisher, Kraków.

Musiaka Ł. (2013), Funkcja turystyczna średniowiecznych zamków i jej wpływ na miasta Pomorza, Warmii i Mazur, Wydawnictwo Uniwersytetu Łódzkiego, Łódź.

Musiaka Ł. (2016), Funkcja turystyczna zamków dawnego państwa krzyżackiego na przykładzie Malborka [w:] J. Hochleitner (red.), Wyzwania turystyki kulturowej w Malborku, Muzeum Zamkowe w Malborku, Malbork.

Musioł-Urbańczyk A., Sorychta-Wojsczyk B. (2017), Przesłanki aktualizacji i bariery implementacji strategii $w$ miastach na prawach powiatu w Polsce, "Zarządzanie Publiczne", 3 (39).

Narodowy Instytut Dziedzictwa, https://www.nid.pl [accessed: 25 June 2018].

Narożniak I. (2002), Szlakiem zamków gotyckich - oferta turystyczna województwa pomorskiego oraz warmińsko-mazurskiego [w:] Zamki gotyckie na szlakach turystycznych Pomorza, Kujaw, Warmii i Mazur. Zbiór materiałów pokonferencyjnych, Sport, Gdańsk.

Partnerstwo Publiczno-Prywatne, http://www.ppp.gov.pl [accessed: 25 June 2018].

Pawłowska K., Swaryczewska M. (2002), Ochrona dziedzictwa kulturowego: zarzqdzanie i partycypacja społeczna, Wydawnictwo Uniwersytetu Jagiellońskiego, Kraków.

Pomorskie.travel (2018) Atrakcje turystyczne województwo pomorskie, http://pomorskie.travel [accessed: 25 June 2018].

Pruszyński J.P. (2001), Dziedzictwo kultury Polski. Jego straty i ochrona prawna, Kraków.

PTTK - Znakowane szlaki turystyczne województwa pomorskiego, http://pomorskieszlakipttk.pl [accessed: 25 June 2018].

Purchla J. (red.) (2009), Raport o systemie ochrony dziedzictwa kulturowego w Polsce po roku 1989, Narodowe Centrum Kultury, Warszawa.

Rouba R. (2005), Funkcja hotelarska pałaców, dworów i zamków w Polsce oraz jej wplyw na otoczenie, maszynopis rozprawy doktorskiej napisanej w Instytucie Geografii Miast i Turyzmu Uniwersytetu Łódzkiego, Łódź.

Rouba R. (2010a), Hotelarstwo w zabytkowych rezydencjach jako czynnik modyfikujacy otoczenie, Łódzkie Towarzystwo Naukowe, Łódź.

Rouba R. (2010b), Przyczynek do dyskusji nad ocenq atrakcyjności obiektów zabytkowych, “Zeszyty Naukowe Uniwersytetu Szczecińskiego. Ekonomiczne Problemy Usług”, 52.

Stasiak A., Rochmińska A. (2011), Regionalne strategie rozwoju turystyki $w$ Polsce - stan w 2010 roku [w:] B. Krakowiak, J. Latosińska (red.), Turystyka polska w latach 19892009, Wydawnictwo Uniwersytetu Łódzkiego, Łódź.

Stowarzyszenie gmin Polskie Zamki Gotyckie, http://zamkigotyckie.org.pl [accessed: 25 June 2018]. 
Struczyński J. (2013), Rekonstrukcje historyczne w ofercie programowej Zamku Gniew [w:] M. Boruszczak (red.), Zamki i twierdze w rozwoju współczesnej turystyki, Fundacja Zamek w Gniewie, Wyższa Szkoła Hotelarstwa i Turystyki, Gdańsk.

Studzieniecki T. (2013), Strategia jako narzędzie rozwoju turystyki w województwie, "Zeszyty Naukowe", 26.

Studzieniecki T., Wołoszyk A. (2013), Zamki i twierdze jako certyfikowane produkty turystyczne w Polsce [w:] M. Boruszczak (red.), Zamki i twierdze w rozwoju współczesnej turystyki, Fundacja Zamek w Gniewie, Wyższa Szkoła Hotelarstwa i Turystyki, Gniew.

Szmygin B. (2007), Dziedzictwo w transformacji. Polskie doświadczenia [w:] M. Murzyn, J. Purchla (red.), Dziedzictwo kulturowe w XXI wieku. Szanse i wyzwania, Międzynarodowe Centrum Kultury, Kraków.

Szmygin B. (2009), Analiza obiektu zabytkowego jako element adaptacji do współczesnych funkcji użytkowych - metodologia Światowego Dziedzictwa [w:] Adaptacja obiektów zabytkowych do współczesnych funkcji, PKN ICOMOS, Warszawa-Lublin.

Szwichtenberg A. (2002), Ocena bonitacyjna atrakcyjności turystycznej Szlaku Zamków Gotyckich Warmii i Mazur [w:] Zamki gotyckie na szlakach turystycznych Pomorza, Kujaw, Warmii i Mazur. Zbiór materiałów pokonferencyjnych, Sport, Gdańsk.

Urząd Miasta i Gminy w Sztumie (2018) Przekazaliśmy zamek Ministrowi Kultury i Dziedzictwa Narodowego, "Sztum - oficjalny portal internetowy Miasta i Gminy Sztum", http:// www.sztum.pl/aktualnosci/przekazalismy-zamek-ministrowi-kultury-i-dziedzictwa-narodowego.html [accessed: 25 June 2018].

Wendt J. (2010), Zamki krzyżackie czynnikiem rozwoju turystyki i markowym produktem Pomorza [w:] M. Boruszczak, Dziedzictwo kulturowe-teraźniejszość-przyszłość, MPŚ, Słupsk.

Wyleżałek J. (red.) (2011), Dziedzictwo kulturowe Polski i jego znaczenie w turystyce, Wyższa Szkoła Turystyki i Języków Obcych, Warszawa.

Zeidler K. (red.) (2014), Prawne aspekty ochrony nieruchomości zabytkowych, Wolters Kluwer, Wydawnictwo Uniwersytetu Gdańskiego, Gdańsk-Warszawa.

\section{Source materials}

Gminny program opieki nad zabytkami miasta Lęborka na lata 2015-2018 (2015), Urząd Miasta Lębork, Lębork.

Koncepcja rozwoju produktów 4 szlaków turystyki kulturowej (2007), Polska Agencja Rozwoju Turystyki S.A., Warszawa.

Lokalny program rewitalizacji Nowego Stawu do roku 2020. Diagnoza obszarów zdegradowanych i rewitalizacji (2015), Urząd Miasta i Gminy Nowy Staw, Nowy Staw.

Program opieki nad zabytkami województwa pomorskiego na lata 2016-2019 (2016), Departament Kultury Urzędu Marszałkowskiego Województwa Pomorskiego, Pomorskie Biuro Planowania Regionalnego, Gdańsk.

Program rozwoju produktów turystycznych województwa pomorskiego na lata 2008-2013 (2008), Urząd Marszałkowski Województwa Pomorskiego - Departament Turystyki, Gdańsk.

Program rozwoju turystyki w Polsce do roku 2020 (projekt z 2014 roku, obszar - Polska).

Program Zagospodarowania Przestrzennego województwa pomorskiego 2030 (2017), Pomorskie Biuro Planowania Regionalnego, Gdańsk. 
Raport o partnerstwie publiczno-prywatnym w Polsce (2013), J. Hausner (red.), Centrum Partnerstwa Publiczno-Prywatnego, Warszawa.

Raport o stanie zachowania zabytków nieruchomych w Polsce. Zabytki wpisane do rejestru zabytków (księgi rejestru A i C) (2017), Narodowy Instytut Dziedzictwa, Warszawa.

Regionalny program operacyjny województwa pomorskiego na lata 2014-2020 (2015), Zarząd Województwa Pomorskiego, Gdańsk.

Regionalny program strategiczny w zakresie atrakcyjności kulturalnej i turystycznej „Pomorska Podróż” (2013), Zarząd Województwa Pomorskiego, Gdańsk.

Strategia rozwoju turystyki województwa pomorskiego na lata 2004-2013 (2004), Urząd Marszałkowski Województwa Pomorskiego, Gdańsk.

Strategia rozwoju województwa pomorskiego do 2020 roku (2012), Sejmik Województwa Pomorskiego, Gdańsk.

Studium uruchomienia całorocznego produktu turystycznego Miejskiego Obszaru Funkcjonalnego Malborka (2014), Agencja Rozwoju Pomorza S.A., Gdańsk. 
